\title{
Use of Bipolar Electrosurgical Device for Sealing of Ureter During Laparoscopic Live Donor Nephrectomy: Single-center Experience
}

\author{
Laparoskopik Donör Nefrektomide Damarların ve Üreterin Mühürlenmesinde Kullanılan \\ Teknikler ve Önemleri: Tek Merkez Deneyimi
}

\author{
(D) Ulaş SÖZENER
}

Medicana International Ankara Hospital, Kidney Transplantation Centre; Atılım University Faculty of Medicine, Department of General Surgery, Ankara, Turkey

\begin{abstract}
Aim: In this study, we evaluated our method of using bipolar sealing and cutting of terminal ureter in donor nephrectomy and discussed its safety and effectiveness.

Materials and Methods: A total of 200 patients who underwent laparoscopic donor nephrectomy between August 2018 and August 2020 were included in the study. All the surgeries were performed by the same surgeon with the same technique. Patient variables including age, gender, body mass index, estimated blood loss, surgical times and postoperative drainage creatinine values were all recorded.

Results: On the first postoperative day, creatinine measurement was performed from drainage collection which was repeated on the second postoperative day. After the second recording of creatinine level, the drain was taken out. In all of the patients, the values were all within ranges of the blood creatinine levels, which was consistent with no urinary leak. We did not need to perform any further invasive test to check for a leak like a cystography.
\end{abstract}

Conclusion: Our results demonstrate that the use of energy devices for sealing vessels can be used safely and effectively for sealing distal ureter.

Keywords: Donor nephrectomy, laparoscopy, kidney transplantation

ÖZ

Amaç: Bu çalışmada, donör nefrektomide bipolar mühürleme ve terminal üreterin kesilmesi yöntemimizi değerlendirdik ve güvenliğini ve etkinliğini tartıştık.

Gereç ve Yöntem: Ağustos 2018 ile Ağustos 2020 tarihleri arasında laparoskopik donör nefrektomi yapılan toplam 200 hasta çalışmaya dahil edildi. Tüm ameliyatlar aynı cerrah tarafından aynı teknikle yapıldı. Yaş, cinsiyet, vücut kitle indeksi, tahmini kan kaybı, cerrahi süreler ve postoperatif drenaj kreatinin değerleri gibi hasta değişkenlerinin tümü kaydedildi.

Bulgular: Postoperatif birinci günde, postoperatif ikinci günde tekrarlanan drenaj koleksiyonundan kreatinin ölçümü yapıldı. İkinci kreatinin düzeyi kaydedildikten sonra dren çekildi. Tüm hastalarda, değerler kan kreatinin seviyeleri aralığında idi ve bu durum idrar kaçağı olmamasıyla tutarlıydı. Sızıntı olup olmadığını kontrol etmek için sistografi gibi invaziv testler yapmamıza gerek olmadı.

Sonuç: Sonuçlarımız damarları kapatmak için kullanılan enerji cihazlarının, distal üreterin kapatılmasında güvenli ve etkili bir şekilde kullanılabileceğini göstermektedir.

Anahtar Kelimeler: Donör nefrektomi, laparoskopi, böbrek nakli

Address for Correspondence: Ulaş SÖZENER MD, Medicana International Ankara Hospital, Kidney Transplantation Centre, Ankara, Turkey Phone: +90 5326641758 E-mail: ulassozener@gmail.com ORCID ID: orcid.org/0000-0001-6719-0062

Received: 31.12.2020 Accepted: 26.01.2021

๑Copyright 2021 by the Tekirdağ Namık Kemal University Faculty of Medicine / Namık Kemal Medical Journal published by Galenos Publishing House. 


\section{INTRODUCTION}

Kidney transplantation is the best treatment for patients with end-stage renal disease, and it provides significantly better survival rates for patients than dialysis. Living donor kidney transplantation is a valuable alternative to cadaveric transplantation in countries with low organ donation rates. Despite having numerous advantages to cadaveric grafts like shorter ischemia time, improved surgical extraction quality, and preemptive transplant access, operating a living, healthy individual brings its own concerns.

Establishing uttermost safety and comfort to donors is paramount for living donor nephrectomy. With advancements like minimal invasive surgery, laparoscopy, retroperitonoscopy and robotic surgery, postoperative donor comfort has significantly improved over the past years'. Usage of sophisticated electrosurgical devices allows the surgeon to perform more precise dissection with less bleeding and less trauma to neighbor tissues. The safety of electro sealing devices allows us to achieve less complicated and faster surgical techniques without worrying about complications.

In this study, we evaluated our method of using bipolar sealing and cutting of terminal ureter in donor nephrectomy and discussed its safety and effectiveness.

\section{MATERIALS AND METHODS}

This study was conducted under the Declaration of Helsinki Ethical Principles and Good Clinical Practices. This study was reviewed and approved by the Ethical Committee of Medicana Interantional Ankara Hospital at 06.01.2021 (approval number: BSH-2020/18). Patient consents were taken. Two-hundred patients who were operated laparoscopic donor nephrectomy (LDN) between August 2018 and August 2020 were enrolled to the study. All the surgeries were performed by same attending transplant surgeon with the same technique. Patient variables including age, gender, body mass index (BMI), estimated blood loss (EBL), surgery time (minutes), postoperative blood creatinine values and drainage fluid creatinine values were all measured and recorded.

A computerized tomography angiogram was performed to all donor candidates for the identification of renal vasculature as well as the anatomy of ureters before the operation.

\section{LDN Technique ${ }^{2}$}

Patient was operated in lateral decubitus position. The technique described by Sozener ${ }^{2}$ was the routine operation procedure. Following periumbilical trocar insertion and insufflation, the abdominal cavity was explored videoscopically. Three to four additional trocars were inserted, as described previously by Ratner et al. ${ }^{3}$. The right or left hemi colon was dissected from the lateral abdominal wall and mobilized medially. Fascia was transected, and the perirenal fatty tissue and other connective tissue was separated. The renal vessels and ureter were dissected. A Pfannenstiel incision ranging 6 to $8 \mathrm{~cm}$ was made. The ureter was dissected to the point of its crossing under the iliac vessel, sealed and divided with LigaSure ${ }^{\mathrm{TM}}$ Blunt Tip Open and Laparoscopic Sealer/Divider with Nano-coating device (Medtronic, Minneapolis, Minn, United States). An automatic cutting laparoscopic stapler was used to divide the renal vessels. Subsequently, the kidney was extracted by hand and cooled immediately.

\section{Statistical Analysis}

Data were analyzed by using SPSS 20 statistical software (SPSS Inc., Chicago, IL, USA). Categorical variables were reported as percentages, while continuous variables were reported as means and standard deviations. For continuous variables, group comparisons were analyzed using the by KruskalWallis test, Student's t-test or analysis of variance followed by Bonferroni posttests in the case that overall $p$ value was significant. Categorical variables were compared with the chisquare test. Patient and graft survival rates were calculated by the Kaplan-Meier method, and the log rank test was used to compare the differences in survival.

\section{RESULTS}

\section{Patient Demographic and Surgical Data}

Among 200 live donors, 92 (46\%) were male, and 108 (54\%) were female. The mean patient age was 48.27 years. The mean BMI was 28.6. The left kidney in $79(77.5 \%)$ cases and the right kidney in $23(22.5 \%)$ cases were retrieved. The mean EBL was 80 milliliters (20-150). The mean surgical time of LDN was (3086) minutes.

A single renal artery was encountered in 165 (82.5\%) donors has a single renal artery, while $33(16.5 \%)$ had double renal arteries. Three renal arteries were present only in $2(1 \%)$ cases. Majority of the donors had a single renal vein (180 donors, $90 \%)$ and $20(10 \%)$ donors had double renal veins. Division of renal artery and vein was performed by the single stapler technique described previous by Genc et al. ${ }^{4}$, Tokaç et al. ${ }^{5}$ and Sozener ${ }^{6}$ in 156 donors (78\%). Stapling of multiple vessels separately was performed in 44 donors (22\%). Minor accessory veins were either sealed by energy device or clipped.

Conversion to the open donor nephrectomy was not required in any operation. No postoperative surgical complication was observed.

Minor morbidities like delayed bowel movement and atelectasis were seen in some patients during postoperative stay but no interventions were necessary beyond simple modifications in 
treatment. Mean hospital stay time was $2.5 \pm 1.5$ days. Main points were summarized in Table 1.

On the first postoperative day, creatinine measurement was performed from drainage collection, which was repeated on the second postoperative day. After the second creatinine level was recorded, the drain was taken out. Since we routinely monitor blood creatinine levels of donors postoperatively, we compared our results with drainage fluid creatinine levels. In all of the patients, the values were all within ranges of the blood creatinine levels, which was consistent with no urinary leak. We did not need to perform any further invasive test, like a cystography, to check for a leak.

\section{DISCUSSION}

Minimally invasive surgery techniques changed the approach to living donor operations drastically. Once considered as a big operation with debilitating effects on the early, mid-term to the patient, new techniques moved donor nephrectomy to the group of surgeries like cholecystectomy, and hernia repair.

While being minimally invasive and more comforting to the patient, safety of the operation and the preservation of the graft can never be compromised. For this purpose, most efficient devices must always be utilized. Sealing on main vessels, for example, should always be performed with

\section{Table 1. Demographic and surgical data}

\begin{tabular}{|l|l|l|}
\hline \multicolumn{1}{|l|}{} & $\mathbf{n}$ & $\%$ \\
\hline Age (years) & $48.27 \pm 12.0$ & \\
\hline Male/female & $92 / 108$ & $46 / 54$ \\
\hline BMI (kg/m²) & $28.6 \pm 2$ & \\
\hline Kidney side (left/right) & $79 / 23$ & \\
\hline EBL (mL) & $80 \pm 10$ & \\
\hline Surgical time (minutes) & $45 \pm 15$ & \\
\hline Arteries & \multicolumn{2}{|l|}{} \\
\hline Single & 165 & 82.5 \\
\hline Two & 33 & 16.5 \\
\hline Three & 2 & 1 \\
\hline Veins & \multicolumn{2}{|l}{} \\
\hline Single & 180 & 90 \\
\hline Double & 20 & 10 \\
\hline Conversion to open surgery & - & - \\
\hline Perioperative/postoperative complications & - & - \\
\hline Stapling of vessels & \multicolumn{2}{|l}{} \\
\hline Single stapler technique & 156 & 78 \\
\hline Multiple staplers & 44 & 22 \\
\hline Ligation and division of ureters & 200 & 100 \\
\hline Ligasure & - & - \\
\hline Other methods & \multicolumn{2}{|l|}{} \\
\hline EBL: Estimated blood loss, BMl: Body mass index & \multicolumn{2}{|l|}{} \\
\hline
\end{tabular}

appropriate vascular stapling devices. For sealing renal arteries, the use of titanium or hem-o-lok polymer clips (Teleflex Medical, PA, United States) are currently contraindicated for living donor nephrectomies.

When we designed the study, our first step was to review the literature for alternative methods of ureter sealing during minimally invasive nephrectomies. The extensive search revealed that although numerous papers were published on the techniques and results on the subject, ligation of ureter was not detailed in any of those studies ${ }^{7-9}$. This is also consistent with the common knowledge that any physiologically normal vesicoureteral junction prevents backflow of urine.

Despite this common knowledge, almost all of the surgeons either ligate the ureteral stump or use hemoclips. This extra maneuver either adds to the time or increases the cost of the surgery. It may seem like an unimportant step but when you substitute this step with a simple sealing maneuver with a device, you already use during the procedure to both reduce the operative time and the cost, however minimum. Our results demonstrate that the use of energy devices for sealing vessels can be used safely and effectively for sealing distal ureter. Added the fact that the suggested maneuver is perfectly fast and easy, it can totally replace the standard ligating/clipping habit.

The guideline of European Association of Urology on transplantation defines ureteral stenosis as a common complication in recipients, with an incidence of $0.6-10.5 \%{ }^{10}$. Early stenosis (within three months of surgery) is usually caused by surgical technique or compromised ureteral blood supply during surgery. Dinckan et al. ${ }^{11}$ and Helfand et al. ${ }^{12}$ suggested that, late stenosis (after >six months) is provoked by infection, fibrosis, progressive vascular disease and/or rejection. Although these factors are not related to the donors, the distal $3 \mathrm{~cm}$ part of the graft ureter is always resected to eliminate risk of thermal damage.

\section{Study Limitations}

This study has limitations in terms of comparing the suggested methods with other methods. Although not considered as a control group, conventional methods for sealing vascular structures and ureter have been firmly established with known and accepted success and failure rates.

\section{CONCLUSION}

To sum up; laparoscopic nephrectomy for transplantation, benign or oncological purposes can be safely and effectively performed. Electro sealing devices are safely and effectively used for vessel sealing but sealing of ureter has not been discussed in the literature. Results of the large group of patients in this study demonstrate the efficiency and ease of use of electro sealing devices for this purpose. 


\section{Ethics}

Ethics Committee Approval: This study was reviewed and approved by the Ethical Committee of Medicana Interantional Ankara Hospital at 06.01.2021 (approval number: BSH2020/18).

Informed Consent: Consent form was filled out by all participants.

Peer-review: Externally peer-reviewed.

Financial Disclosure: The author declared that this study received no financial support.

\section{References}

1. Kok NF, Weimar W, Alwayn IP, ljzermans JN. The current practice of live donor nephrectomy in Europe. Transplantation. 2006;82:892-7.

2. Sozener U. Laparoscopic Live Donor Nephrectomy: Single-Center Experience of 200 Consecutive Cases. J Laparoendosc Adv Surg Tech A. 2020 Jul 27.

3. Ratner LE, Ciseck $\sqcup$, Moore RG, Cigarroa FG, Kaufman HS, Kavoussi LR. Laparoscopic live donor nephrectomy. Transplantation. 1995;60:1047-9.

4. Genc V, Orozakunov E, Ozgencil E, Can OS, Yilmaz AA, Cipe G, et al. Single Stapler technique in laparoscopic donor nephrectomy. Transplant Proc. 2011:43:787-90.
5. Tokaç M, Eren E, Özçelik Ü, Şahin T, Dinçkan A. Renal Hilus Ligation With Single Stapler in Laparoscopic Donor Nephrectomy. Transplant Proc. 2019:51:2225-7.

6. Sozener U. Single Stapler Technique for Vascular Control in Laparoscopic Donor Nephrectomy. Transplant Proc. 2020;S0041-1345(20)32689-0. Online Ahead of Print.

7. Rassweiler JJ, Henkel TO, Potempa DM, Coptcoat M, Alken P. The technique of transperitoneal laparoscopic nephrectomy, adrenalectomy and nephroureterectomy. Eur Urol. 1993;23:425-30.

8. Allan JD, Tolley DA, Kaouk JH, Novick AC, Gill IS. Laparoscopic radical nephrectomy. Eur Urol. 2001;40:17-23.

9. El-Galley R, Hood N, Young CJ, Deierhoi M, Urban DA. Donor nephrectomy: A comparison of techniques and results of open, hand assisted and full laparoscopic nephrectomy. J Urol. 2004;171:40-3.

10. Breda A, Bui MH, Liao JC, Gritsch HA, Schulam PG. Incidence of ureteral strictures after laparoscopic donor nephrectomy. J Urol. 2006;176:1065-8.

11. Dinckan A, Tekin A, Turkyilmaz S, Kocak H, Gurkan A, Erdogan O, et al. Early and late urological complications corrected surgically following renal transplantation. Transpl Int. 2007;20:702-7.

12. Helfand BT, Newman JP, Mongiu AK, Modi P, Meeks JJ, Gonzalez CM. Reconstruction of late-onset transplant ureteral stricture disease. BJU Int 2011;107:982-7. 